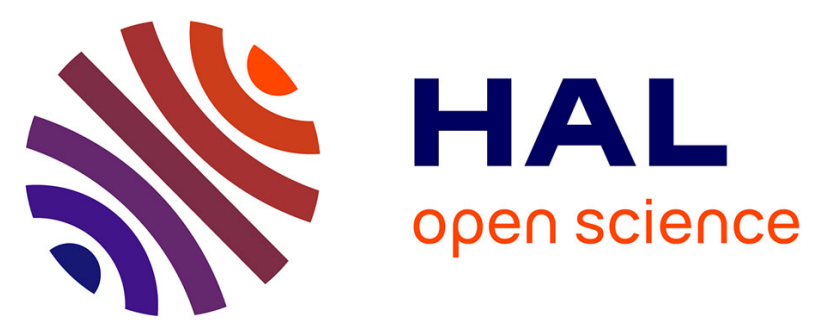

\title{
Stability of bacterial carotenoids in the presence of iron in a model of the gastric compartment - Comparison with dietary reference carotenoids
}

\author{
Charlotte Sy, Olivier Dangles, Patrick Borel, Catherine Caris-Veyrat
}

\section{- To cite this version:}

Charlotte Sy, Olivier Dangles, Patrick Borel, Catherine Caris-Veyrat. Stability of bacterial carotenoids in the presence of iron in a model of the gastric compartment - Comparison with dietary reference carotenoids. Archives of Biochemistry and Biophysics, 2015, 572, pp.89 - 100. 10.1016/j.abb.2014.12.030 . inserm-01478394

\section{HAL Id: inserm-01478394 https://www.hal.inserm.fr/inserm-01478394}

Submitted on 27 May 2020

HAL is a multi-disciplinary open access archive for the deposit and dissemination of scientific research documents, whether they are published or not. The documents may come from teaching and research institutions in France or abroad, or from public or private research centers.
L'archive ouverte pluridisciplinaire HAL, est destinée au dépôt et à la diffusion de documents scientifiques de niveau recherche, publiés ou non, émanant des établissements d'enseignement et de recherche français ou étrangers, des laboratoires publics ou privés. 


\title{
Stability of bacterial carotenoids in the presence of iron in a model of the gastric compartment - Comparison with dietary reference carotenoids
}

\author{
Charlotte Sy $^{\mathrm{a}, \mathrm{b}, \mathrm{c}, \mathrm{d}, \mathrm{e}}$, Olivier Dangles ${ }^{\mathrm{a}, \mathrm{b}}$, Patrick Borel ${ }^{\mathrm{c}, \mathrm{d}, \mathrm{e}}$, Catherine Caris-Veyrat ${ }^{\mathrm{a}, \mathrm{b}, *}$ \\ a INRA, UMR408 Sécurité et Qualité des Produits d'Origine Végétale, F-84000 Avignon, France \\ ${ }^{\mathrm{b}}$ Université d'Avignon et des Pays du Vaucluse, UMR408 Sécurité et Qualité des Produits d'Origine Végétale, F-84000 Avignon, France \\ ' INRA, UMR1260 Nutrition, Obésité et Risque Thrombotique, F-13385 Marseille, France \\ ${ }^{\mathrm{d}}$ INSERM, UMR 1062, F-13385 Marseille, France \\ 'Aix-Marseille Université, Faculté de Médecine, F-13385 Marseille, France
}

Keywords:

$\beta$-Carotene

Lycopene

Astaxanthin

Carotenoids from bacteria

Transition metal

Metmyoglobin

Gastric model

Degradation

Oxidation

\begin{abstract}
A B S T R A C T
Recently isolated spore-forming pigmented marine bacteria, Bacillus indicus HU36 and Bacillus firmus GB1 are sources of carotenoids ( $\sim$ fifteen distinct yellow and orange pigments and $\sim$ thirteen distinct pink pigments, respectively). They are glycosides of oxygenated lycopene derivatives (apo-lycopenoids) and are assumed to be more heat- and gastric-stable than common carotenoids. In this study, the oxidation by $\mathrm{O}_{2}$ of the bacterial carotenoids was initiated by free iron ( $\mathrm{Fe}^{\mathrm{II}}$ and $\mathrm{Fe}^{\mathrm{III}}$ ) or by heme iron (metmyoglobin) in a mildly acidic aqueous solution mimicking the gastro-intestinal compartment and compared to the oxidation of the common dietary carotenoids $\beta$-carotene, lycopene and astaxanthin. Under these conditions, all bacterial carotenoids appear more stable in the presence of heme iron vs. free iron. Carotenoid autoxidation initiated by $\mathrm{Fe}^{\mathrm{II}}$ is relatively fast and likely involves reactive oxygen-iron species derived from $\mathrm{Fe}^{\mathrm{II}}$ and $\mathrm{O}_{2}$. By contrast, the corresponding reaction with $\mathrm{Fe}^{\mathrm{III}}$ is kinetically blocked by the slow preliminary reduction of $\mathrm{Fe}^{\mathrm{III}}$ into $\mathrm{Fe}^{\mathrm{II}}$ by the carotenoids. The stability of carotenoids toward autoxidation increases as follows: $\beta$-carotene < lycopene < astaxanthin < HU36 and GB1. In particular, bacterial carotenoids react more quickly than reference carotenoids with $\mathrm{Fe}^{\mathrm{III}}$, but much more slowly than the reference carotenoids with Fe ${ }^{\text {II }}$. This reaction is correlated with the structure of the carotenoids, which can have opposite effects in a micellar system: bacterial carotenoids with electro-attracting terminal groups have a lower reducing capacity than $\beta$-carotene and lycopene. However, their polar head favours their location close to the interface of micelles, in closer contact with oxidative species. Kinetic analyses of the ironinduced autoxidation of astaxanthin and HU36 carotenoids has been performed and gives insights in the underlying mechanisms.
\end{abstract}

\section{Introduction}

Carotenoids impart both organoleptic and nutritional properties to fresh and processed foods. They provide red, orange or yellow colouration not only to fruit and vegetables, but also to other food products such as egg yolks, poultry skin, crustaceans, and also numerous processed products in which they are added as colouring agents. When consumed either in foods or supplements, they can exert effects on health, either as precursors of vitamin A, or potentially in the prevention of degenerative or age-related diseases $[44,10,25,46,50,49,26]$. Aside from their antioxidant activity

* Corresponding author at: UMR408 Sécurité et Qualité des Produits d'Origine Végétale, INRA Centre de Recherche PACA, 228 route de l'Aérodrome, CS 40509 Domaine Saint Paul - Site Agroparc, 84914 Avignon Cedex 9 France.

E-mail address: catherine.caris@avignon.inra.fr (C. Caris-Veyrat).
$[13,53,14,2,51]$, other protective but non-antioxidant properties have been reported including retinoid-dependent signalling, cell communication, regulation of gene expression, and filtering of blue light $[52,41]$.

However, many factors can influence the stability of carotenoids [4]. In the presence of dioxygen, carotenoids are susceptible to autoxidation, and several types of oxidation products can be formed [21,37,16,34,56,22,29,48,9]. After ingestion, carotenoids are submitted to the reactive conditions of the stomach, i.e., the presence of dioxygen, a temperature of $37^{\circ} \mathrm{C}$, a $\mathrm{pH}$ varying between 6 and 2, constant mixing, the presence of reactive species such as oxidizable lipids and iron [27]. Indeed iron is present in foods both as heme iron (in red meat) and as the free form $[31,45]$. Iron could interact with carotenoids either directly by initiating their autoxidation $[3,4]$ or indirectly by initiating lipid peroxidation and the concomitant oxidation of carotenoids by lipid 
Version définitive du manuscrit publiée dans / Final version of the manuscript published in :

Archives of Biochemistry and Biophysics (2015), Vol. 572, p. 89-100, DOI: 10.1016/j.abb.2014.12.030

Journal homepage : http://www.elsevier.com/locate/yabbi

peroxyl radicals [1,15]. Previous research suggests that this phenomena is likely to occur in the gastro-intestinal tract [30].

Bacterial carotenoids have gained popularity in the past few years due to their ability to provide a sustainable biosource of carotenoids for the food and feed industries [12]. A wide range of coloured spore-forming Bacillus species has been isolated [11,42]. They synthesize various red, pink or yellow-orange carotenoids with original structures, which impart specific properties (e.g., solubility, stability) that differ from the more prevalent carotenoids found in fruit and vegetables. In higher plants, algae, and fungi, the carotenoids produced contain a $\mathrm{C}_{40}$ scaffold, while bacteria can produce a diverse range of carotenoids with $C_{30}, C_{40}, C_{45}$ or even $C_{50}$ backbones [7]. Bacterial carotenoids bearing a short chain backbone (e.g., $<\mathrm{C}_{40}$ ) are called apo- or diapo-carotenoids depending on whether one or both sides of the backbone have been truncated, respectively. For instance, 4,4'-diapo-carotenoids have been found in some of Gram+ bacteria such as Methylobacterium rhodinum, Streptococcus faecium, Heliobacteria, Staphylococcus aureus, and apo- $8^{\prime}$-carotenoids were identified in Planococcus and Halobacillus [42].

In the work presented herein, we have investigated novel carotenoids extracted from two marine bacterial strains for their sensitivity to oxidative stress in conditions mimicking the gastric compartment. Initially, the Bacillus indicus HU36 and mutant Bacillus firmus GB1 strains were selected for their high carotenoid production, the resistance of their spores to UV radiation [28] and their probiotic properties [23]. The HU36 strain was isolated from human faeces and synthesizes yellow and orange pigments (Fig. 1) in variable proportions depending on whether it is in the vegetative cell or spore phase [28]. The corresponding carotenoid-rich extract absorbs visible light at $429,454\left(\lambda_{\max }\right)$ and $485 \mathrm{~nm}$ (shoulder). The most abundant pigments in the extract are the yellow coloured 1-glycosyl-3,4-dehydro-apo-8'-lycopene products which differ only in the length of the saturated fatty acid chain (C8:0C15:0) esterified to the glycosyl moiety and orange coloured methyl-1-glycosyl-3,4-dehydro-apo-8'-lycopenoate products which also differ only in the length of the saturated fatty acid chain (C9:0-C11:0) esterified to the glycosyl moiety [42]. The GB1 strain was isolated from human ileum [24] and produces deep-pink pigments which absorb visible light at $463,492\left(\lambda_{\max }\right)$ and $524 \mathrm{~nm}$ (shoulder) [28]. In the GB1 strain, the main pigment is 4,4'-diglycosyl-4,4'-diapolycopenoic diester (Fig. 1).

In this study, free iron $[17,58,18]$ and heme iron, i.e., metmyoglobin, $[54,55]$ were compared for their propensity to induce carotenoid autoxidation in a medium mimicking the environment in the human gastric compartment. As a prerequisite for intestinal absorption, dietary carotenoids must be incorporated into micelles mainly composed of phospholipids, cholesterol and triglyceride digestion products (fatty acids, monoglycerides) [5,57]. In this study, we used a simple micellar system with polyoxyethylene glycol 23 lauryl ether (Brij ${ }^{\circledR}$ L23) to solubilize carotenoids in the aqueous medium. Brij ${ }^{\circledR}$ L23 is a synthetic non-ionic surfactant which we selected for its relatively low content in hydroperoxides [32] and its low UV cut-off. Three reference carotenoids were selected for comparison with the HU36 and GB1 bacterial carotenoids because they are common in food products: $\beta$-carotene, lycopene (two carotenes prevalent in fruit and vegetables) and astaxanthin (a xanthophyll found in microalgae and yeast, and present in fish and crustaceans). These carotenoids are among the most popular carotenoids commercially developed and sold in synthetic or natural forms in today's marketplace [38]. After the investigation of the kinetics of iron-induced carotenoid autoxidation, the degradation products of carotenoids were investigated using UPLC-DAD-MS and GC-MS analyses and mechanisms were studied.

\section{Materials and methods}

\section{Materials}

(all-E)-lycopene (>90\%) purified from tomato oleoresin was obtained from Conesa (Conservas Vegetales de Extremadura, Badajoz, Spain). Carotenoid extracts from Bacillus strains (HU36 and<smiles>CC1=C(/C=C/C(C)=C/C=C/C(C)=C/C=C/C=C(C)/C=C/C=C(C)/C=C/C2=C(C)CCCC2(C)C)C(C)(C)CCC1</smiles><smiles>CC(C)=CCC/C(C)=C/C=C/C(C)=C/C=C/C(C)=C/C=C/C=C(C)/C=C/C=C(C)/C=C/C=C(\C)CCC=C(C)C</smiles><smiles>CC1=C(/C=C/C(C)=C/C=C/C(C)=C/C=C/C=C(C)/C=C/C=C(C)/C=C/C2=C(C)C(=O)[C@@H](O)CC2(C)C)C(C)(C)C[C@H](O)C1=O</smiles>

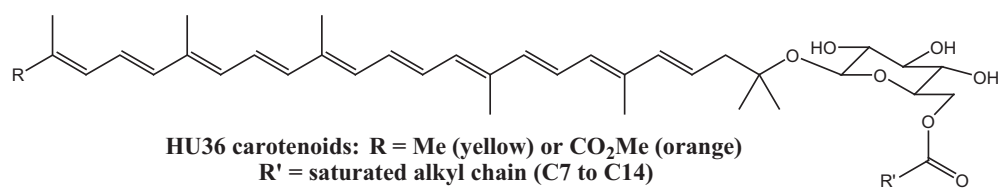

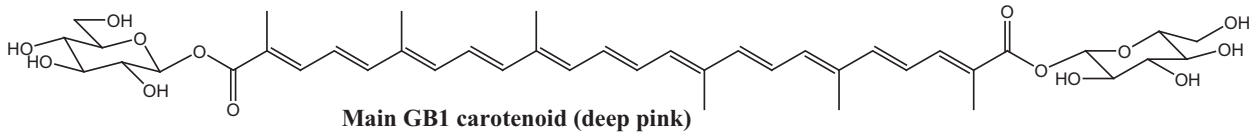

Fig. 1. Structures of the reference and bacterial carotenoids. 
GB1) were provided by members of the Colorspore project consortium [11]. Type II synthetic (all-E)- $\beta$-carotene (>95\%), synthetic (all-E)-astaxanthin (>98\%), polyoxyethylene glycol (23) lauryl ether ( $\mathrm{Brij}^{\otimes} \mathrm{L} 23$ ), $\mathrm{FeSO}_{4} \cdot 7 \mathrm{H}_{2} \mathrm{O}(>99.5 \%), \mathrm{Fe}\left(\mathrm{NO}_{3}\right)_{3} \cdot 9 \mathrm{H}_{2} \mathrm{O}$ (98\%), myoglobin from equine heart ( $>90 \%$, essentially salt-free), ammonium formate (99.995\%), anhydrous sodium sulphate (>99\%), sodium chloride (>99.5\%), $\beta$-cyclocitral $\left(\mathrm{C}_{10} \mathrm{H}_{16} \mathrm{O},>90 \%\right), \beta$-ionone $(>96 \%)$ and 6-methyl-5-hepten-2-one $(>98 \%)$ were purchased from Sigma-Aldrich (St-Quentin-Fallavier, France). Formic acid (>98\%) and LC-MS grade methanol were purchased from Merck (Darmstadt, Germany). LC-MS grade acetonitrile, HPLC grade methylene chloride and n-hexane, analytical grade ethyl acetate and isopropanol were purchased from Fisher-Scientific (Loughborough, UK). Deionized water was obtained from a Millipore Q-Plus.

\section{UV-visible spectroscopy}

All spectra were recorded at $25^{\circ} \mathrm{C}$ on a Specord S-600 diode-array UV-vis spectrophotometer (optical pathlength $=1 \mathrm{~cm}$ ) equipped with an 8-cell rail, a magnetic stirring device, and a thermostatic bath (Analytic Jena).

\section{Carotenoid stock solutions}

The crude bacterial extracts of HU36 and GB1 were dissolved in $\mathrm{CH}_{2} \mathrm{Cl}_{2} / \mathrm{MeOH}(1: 1, \mathrm{v} / \mathrm{v})$. Cocktails of purified bacterial carotenoids ( $\sim 90 \%)$ were obtained by injecting the crude extracts by liquid chromatography on a $\mathrm{C}_{18}$ column and collecting the eluent. The eluent was then evaporated and redissolved in $\mathrm{CH}_{2} \mathrm{Cl}_{2} / \mathrm{MeOH}$ $(1: 1, v / v)$. Three pure carotenoids were chosen as standards to evaluate the stability of bacterial carotenoids: synthetic (all-E)- $\beta$ carotene, natural (all-E)-lycopene from tomato oleoresin and synthetic (all-E)-astaxanthin. Stock carotenoid solutions $\left(\sim 500 \mu \mathrm{mol} \mathrm{L}^{-1}\right)$ were prepared by dissolving the dry standards (2.68 $\mathrm{mg} \beta$-carotene and lycopene, $2.98 \mathrm{mg}$ astaxanthin, $3.75 \mathrm{mg}$ HU36 carotenoids and $3.90 \mathrm{mg} \mathrm{GB} 1$ carotenoids) in $10 \mathrm{~mL} \mathrm{CH} \mathrm{Cl}_{2}$. The concentrations of stock carotenoid solutions were calculated using molar absorption coefficients: $128.5 \times 10^{3} \mathrm{~L} \mathrm{~mol}^{-1} \mathrm{~cm}^{-1}$ at $460 \mathrm{~nm}$ for $\beta$-carotene [6], $178 \times 10^{3} \mathrm{~L} \mathrm{~mol}^{-1} \mathrm{~cm}^{-1}$ at $482 \mathrm{~nm}$ for lycopene, $125 \times 10^{3} \mathrm{~L} \mathrm{~mol}^{-1} \mathrm{~cm}^{-1}$ at $486 \mathrm{~nm}$ for astaxanthin, $165 \times 10^{3} \mathrm{~L} \mathrm{~mol}^{-1} \mathrm{~cm}^{-1}$ at $454 \mathrm{~nm}$ for HU36 carotenoids and $225.3 \times 10^{3} \mathrm{~L} \mathrm{~mol}^{-1} \mathrm{~cm}^{-1}$ at $502 \mathrm{~nm}$ for GB1 carotenoids in $\mathrm{CH}_{2} \mathrm{Cl}_{2}$. The average molecular weights of the carotenoid cocktails from HU36 and GB1 were 750 and $784 \mathrm{~g} \mathrm{~mol}^{-1}$, respectively, and their molar absorption coefficients were estimated from the literature [33].

\section{Carotenoid micelle solutions}

Experiments were carried out in an aqueous solution at $\mathrm{pH} 4$ to approach postprandial digestion conditions in the stomach [57]. A $0.2 \mathrm{~mol} \mathrm{~L}^{-1}$ acetate buffer solution was chosen (no significant iron-chelating capacity). Purification of the buffer (to remove any potential metal contaminants) was achieved by passing the solution through a chelating resin (Chelex $100^{\circledR}$, Bio-Rad).

Brij ${ }^{\circledR} \mathrm{L} 23$ (2.42 mg) was dissolved in $\mathrm{CH}_{2} \mathrm{Cl}_{2}(50 \mathrm{~mL})$ to obtain a $40 \mathrm{mmol} \mathrm{L}^{-1}$ stock solution.

Aliquots of stock carotenoid solutions (about $400 \mu \mathrm{L}$ ) were mixed with $2 \mathrm{~mL}$ stock surfactant solution and the solvent was evaporated under reduced pressure. The residue was dissolved using a magnetic stirring in $20 \mathrm{~mL}$ acetate buffer in order to obtain a concentration of $10 \mu \mathrm{mol} \mathrm{L}{ }^{-1}$ carotenoid and $4 \mathrm{mmol} \mathrm{L}^{-1} \mathrm{Brij}^{\circledR}$ L23.

\section{Iron solutions}

A $500 \mathrm{mmol} \mathrm{L}^{-1} \mathrm{Fe}^{\mathrm{III}}$ stock solution was prepared by dissolving

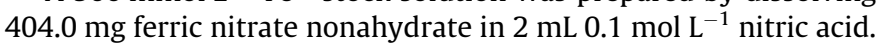
A $500 \mathrm{mmol} \mathrm{L}^{-1} \mathrm{Fe}^{\mathrm{II}}$ stock solution was prepared by dissolving $279.4 \mathrm{mg}$ ferrous sulphate heptahydrate in $2 \mathrm{~mL}^{0.1} \mathrm{~mol} \mathrm{~L}^{-1}$ sulphuric acid. A $500 \mu \mathrm{mol} \mathrm{L}^{-1}$ stock MbFe solution was prepared by dissolving $8.9 \mathrm{mg}$ myoglobin from equine heart in $1 \mathrm{~mL}$ milliQ water. Because of the poor solubility of myoglobin, the stock solution was filtered and its concentration was determined using the molar absorption coefficient $\left(\varepsilon=97 \times 10^{3} \mathrm{~L} \mathrm{~mol}^{1} \mathrm{~cm}^{-1}\right.$ at $\left.505 \mathrm{~nm}\right)$ [35]. Diluted iron solutions were then prepared by dilution of the respective stock solutions. Seven $\mathrm{Fe}^{\mathrm{III}}$ and $\mathrm{Fe}^{\mathrm{II}}$ solutions of various concentrations were made using $0.1 \mathrm{~mol} \mathrm{~L}^{-1}$ nitric acid: $25,12.5$, $5,2.5,0.50,0.25$ and $0.05 \mathrm{mmol} \mathrm{L}^{-1}$. Seven MbFe solutions were made using milliQ water: 500, 250, 50, 25, 5, 2.5 and $0.5 \mu \mathrm{mol} \mathrm{L}^{-1}$.

\section{Iron-induced autoxidation of carotenoids}

For kinetic measurements, the micellar system was divided into a series of macro quartz spectrophotometer cells ( $1.96 \mathrm{~mL}$ per cell). A volume of diluted iron solutions $(40 \mu \mathrm{L})$ was injected in the medium at $t=0$, to produce initial concentrations of $1,5,10,50,100$, 250,500 and $1000 \mu \mathrm{mol} \mathrm{L}^{-1}$ of free iron, or $0.01,0.05,0.1,0.5$, 1.0, 5.0 and $10 \mu \mathrm{mol} \mathrm{L}^{-1}$ of heme iron (metmyoglobin). A control experiment was performed without added iron. Cells were protected from light, covered with Teflon stoppers, and kept under magnetic stirring at a constant temperature of $37^{\circ} \mathrm{C}$. Each treatment was run in triplicate.

\section{Measurement of the total concentration of carotenoids}

Concentrations of residual carotenoids in the micellar medium were measured directly by UV-visible spectroscopy (with the baseline measure of acetate buffer alone). Spectra were recorded over $4 \mathrm{~h}$ from 300 to $1000 \mathrm{~nm}$ and kinetic curves were plotted at the wavelength of maximal absorption.

\section{Kinetic analyses}

Kinetic curves ( $n=3$ for each condition) were analysed by mathematical modelling. Curve-fittings of the percentage of residual carotenoid $v s$. time plots were carried out using the Scientist software (MicroMath, Salt Lake City, USA). They were achieved through least square regression and yielded optimized values for the parameters. Standard deviations are provided in the figures and table. Different letters indicate significant differences $(P<0.05)$ between means (ANOVA and Tukey-Kramer test).

\section{Samples for the structural analysis of oxidation products}

After autoxidation for $4 \mathrm{~h}, 2 \mathrm{~mL}$ of the reaction medium was

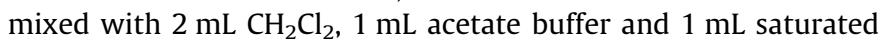
$\mathrm{NaCl}$ solution to quench the reaction and extract the carotenoid. The mixture was vortexed and centrifuged at $10^{4} \mathrm{rpm}$ (Galaxy digital type 7D, with rotor $12 \times 1.5 / 2.0 \mathrm{~mL}$, VWR, Fontenay-sous-Bois, France) for $3 \mathrm{~min}$ to separate the organic and aqueous phases. The lower organic phase was collected and dried with the addition of anhydrous sodium sulphate and again centrifuged at $10^{4} \mathrm{rpm}$ for $1 \mathrm{~min}$. The extract was purified by solid phase extraction on Strata $^{\mathrm{TM}}$ Si-1 silica SPE cartridges (Phenomenex, France). The surfactant was adsorbed on silica and the carotenoid and its derivatives were eluted with $4 \mathrm{~mL}$ of hexane/ $\mathrm{CH}_{2} \mathrm{Cl}_{2}(1: 1, \mathrm{v} / \mathrm{v})$ and then $4 \mathrm{~mL}$ hexane/isopropanol $(4: 1, \mathrm{v} / \mathrm{v})$. The eluent was evaporated under reduced pressure, redissolved in $2 \mathrm{~mL} \mathrm{MeOH} / \mathrm{CH}_{2} \mathrm{Cl}_{2}$ $(1: 1, v / v)$ and filtered through a $0.2 \mu \mathrm{m}$ PTFE syringe filter 
(Phenomenex, France) before being transferred to HPLC vials. Samples were evaporated to dryness under argon and redissolved in $100 \mu \mathrm{L} \mathrm{MeOH} / \mathrm{CH}_{2} \mathrm{Cl}_{2}(1: 1, \mathrm{v} / \mathrm{v})$ just before injection.

\section{Analyses of carotenoid derivatives by UPLC-DAD-MS}

Reversed-phase ultra performance liquid chromatography (UPLC) ${ }^{1}$ analyses were performed on a Waters Acquity ${ }^{\mathrm{TM}}$ UPLC system equipped with a diode array detector (DAD) and coupled to a Bruker-Daltonics ion trap mass spectrophotometer (esquire HCT). A Waters Acquity reversed-phase $C_{18}$ column type HSS T3 $(2.1 \times 150 \mathrm{~mm}, 1.8 \mu \mathrm{m}$ particle size $)$ was used. For the separation, gradient elution was performed at $35^{\circ} \mathrm{C}$, and a flow rate of $0.5 \mathrm{~mL} \mathrm{~min}^{-1}$. Eluent A contained $5 \mu \mathrm{mol} / \mathrm{L} \mathrm{HCOOH}$ and $10 \mathrm{mmol} \mathrm{L}^{-1}$ $\mathrm{HCOONH}_{4}$ in $\mathrm{MeCN} / \mathrm{MeOH} / \mathrm{H}_{2} \mathrm{O}(60: 20: 20, \mathrm{v} / \mathrm{v} / \mathrm{v})$. Eluent B contained $5 \mu \mathrm{mol} / \mathrm{L} \mathrm{HCOOH}$ in EtOAc/ $\mathrm{CH}_{2} \mathrm{Cl}_{2}(80: 20, \mathrm{v} / \mathrm{v})$. For the analysis of $\beta-$ carotene, lycopene, HU36 and GB1 carotenoids, the gradient was as follows: holding $0 \% \mathrm{~B}$ for $2 \mathrm{~min}$, increasing to $55 \% \mathrm{~B}$ over $12.5 \mathrm{~min}$, holding $55 \% \mathrm{~B}$ for $0.5 \mathrm{~min}$, increasing to $60 \% \mathrm{~B}$ over $7 \mathrm{~min}$, increasing to $70 \% \mathrm{~B}$ over $3 \mathrm{~min}$, holding $70 \% \mathrm{~B}$ for $1 \mathrm{~min}$ and returning to $0 \% \mathrm{~B}$ and holding for $2 \mathrm{~min}$. For the analysis of astaxanthin, the gradient was as follows: holding $0 \% \mathrm{~B}$ for $2 \mathrm{~min}$, increasing to $10 \% \mathrm{~B}$ over $5 \mathrm{~min}$, increasing to $45 \% \mathrm{~B}$ over $8 \mathrm{~min}$, increasing to $60 \% \mathrm{~B}$ over $1 \mathrm{~min}$, and returning to $0 \% \mathrm{~B}$ and holding for $2 \mathrm{~min}$. Absorbance was measured every $2 \mathrm{~nm}$ from 250 to $800 \mathrm{~nm}$ with a time interval of $0.1 \mathrm{~min}$. The effluent of the column was interfaced with the MS ion source using an APCI probe alternating between positive and negative modes. MS settings were as follows: corona $=1 \mu \mathrm{A}$, nebulizer gas pressure $=40 \mathrm{psi}$, dry gas flow rate $=4 \mathrm{~L} \mathrm{~min}^{-1}$, temperature of dry gas $=300^{\circ} \mathrm{C}$, vaporizer temperature $=300^{\circ} \mathrm{C}$. A mass range of $50-$ $1000 \mathrm{~m} / \mathrm{z}$ was scanned every $40 \mathrm{~ms}$. Parent ion detection was further focused at various time points during the run to maximize signal by selecting target parent ions around which the MS would focus. The $\mathrm{m} / \mathrm{z}$ selected were as follows: $\beta$-carotene, $300 \mathrm{~m} / \mathrm{z}$ was targeted from $t=0-12.5 \mathrm{~min}$ and $500 \mathrm{~m} / \mathrm{z}$ from 12.5 to $26 \mathrm{~min}$; lycopene, $300 \mathrm{~m} / \mathrm{z}$ was targeted from 0 to $6 \mathrm{~min}$ and $500 \mathrm{~m} / z$ from 6 to $26 \mathrm{~min}$, astaxanthin, $300 \mathrm{~m} / \mathrm{z}$ from 0 to $7 \mathrm{~min}$ and $500 \mathrm{~m} / \mathrm{z}$ from 7 to $16 \mathrm{~min}, 350 \mathrm{~m} / \mathrm{z}$ from 0 to $7 \mathrm{~min}$ and $600 \mathrm{~m} / \mathrm{z}$ from 7 to $11.5 \mathrm{~min} ; 750 \mathrm{~m} / \mathrm{z}$ for $t=11.5-26$ min with bacterial carotenoids. Data analysis was performed using Compass software, version 1.3 (Bruker Daltonics).

\section{Determination of volatile compounds by GC-MS}

GC analysis was performed using a Shimadzu GC QP 20120 equipped with a liner (inner diameter $0.75 \mathrm{~mm}$ ) and coupled to a mass spectrometer. Iron-induced carotenoid autoxidation was carried out with small volumes of solution ( $3 \mathrm{~mL}$ ) in $20 \mathrm{~mL}$ glass flasks closed with a Teflon cap and stirred at $250 \mathrm{rpms}$ at $37^{\circ} \mathrm{C}$ for $280 \mathrm{~min}$. Solid phase microextraction of the volatile compounds was performed directly in the head-space with a Supelco carboxen/polydimethylsiloxane (PDMS) fibre (length $10 \mathrm{~mm}$, film width $0.75 \mu \mathrm{m}$ ) for $25 \mathrm{~min}$ after $15 \mathrm{~min}$ of enrichment. Direct splitless injection was carried out in GC with helium (velocity $=38 \mathrm{~cm} \mathrm{~s}^{-1}$ ) and volatile organic compounds were separated for $32 \mathrm{~min}$ on a Varian capillary CP-Sil 8 CB column (5\% phenylmethyl polysiloxane, $30 \mathrm{~m}$ length, $0.25 \mathrm{~mm}$ internal diameter, $0.5 \mu \mathrm{m}$ film with) using the following conditions: $50^{\circ} \mathrm{C}$ for $2 \mathrm{~min}$, increased to $150{ }^{\circ} \mathrm{C}\left(5^{\circ} \mathrm{C} \mathrm{min}^{-1}\right)$, increase to $250{ }^{\circ} \mathrm{C}\left(20^{\circ} \mathrm{C} \mathrm{min}^{-1}\right)$, then $2 \mathrm{~min}$ at $250^{\circ} \mathrm{C}$. The MS was operated in scanning mode between $\mathrm{m} /$ $z=29$ to 300 , at a speed of 4 scans $\mathrm{s}^{-1}$ and with energy of electronic impact $=70 \mathrm{eV}$. Product identification was based on the National Institute of Standards and Technology (NIST) databank.

\footnotetext{
${ }^{1}$ Abbreviations used: UPLC, Ultra performance liquid chromatography; DAD, diode array detector; NIST, National Institute of Standards and Technology; AST,
} astaxanthin.

\section{Results}

Influence of iron on carotenoid autoxidation in Brij ${ }^{\circledR}$ L23 micelles

The concentration of residual carotenoids was followed by UVvisible spectroscopy at $\lambda_{\max }=460 \mathrm{~nm}$ for $\beta$-carotene, $482 \mathrm{~nm}$ for lycopene, $486 \mathrm{~nm}$ for astaxanthin, $456.5 \mathrm{~nm}$ for HU36 and $500.5 \mathrm{~nm}$ for GB1. Results were expressed as: \% residual carotenoids $=\left[A\left(\lambda_{\max }\right)_{\mathrm{t}} / A\left(\lambda_{\max }\right)_{\mathrm{t} 0}\right] \times 100$, with $A_{(\mathrm{t} 0)}=$ initial absorbance (just before the addition of iron).

At $\mathrm{pH} 4$ in the absence of iron, carotenoid concentrations remained almost constant. The slight consumption observed was associated with spontaneous autoxidation due to unidentified contaminating metal traces.

In the presence of $\mathrm{Fe}^{\mathrm{II}}$, carotenoid consumption began immediately. Lycopene, astaxanthin and $\beta$-carotene (not shown), degradation was rapid and extensive (Figs. 2A and 3A). In the case of GB1 and HU36 (not shown) carotenoids, two steps were observed: a step of fast consumption, followed by a slower one that resulted in more residual carotenoids at the end of the kinetic runs (Fig. 4A). As iron concentrations increased, the mean rate of carotenoid consumption over $4 \mathrm{~h}$ increased up to 5 equiv. $\mathrm{Fe}^{\mathrm{II}}$ for the reference carotenoids, and 1 equiv. $\mathrm{Fe}^{\mathrm{II}}$ for the bacterial carotenoids. At higher concentrations, an unexpected slowing-down was observed.

In the presence of $\mathrm{Fe}^{\mathrm{III}}$, the consumption of lycopene, $\beta$-carotene (not shown), and especially astaxanthin, began slowly with an induction period lasting approximately 20,5 , and $45 \mathrm{~min}$, respectively. Then, autoxidation became faster and the carotenoid concentration decreased sharply (Figs. 2B and 3B). These biphasic kinetics of carotenoid consumption were not observed with bacterial carotenoids from GB1 (Fig. 4B) and HU36 (not shown). For Fe $\mathrm{III}^{\mathrm{II}}$ concentrations higher than 5 equiv. Fe $\mathrm{III}^{\mathrm{II}}$ (10 equiv. for GB1 carotenoids), the rate of carotenoid consumption did not increase further. After $4 \mathrm{~h}$, carotenoid consumption was maximal with 5 equiv. $\mathrm{Fe}^{\mathrm{III}}$ for all carotenoids, except those from GB1 (10 equiv.).

The kinetic profiles of carotenoid consumption were very different when $\mathrm{MbFe}^{\mathrm{III}}$ was the initiator. After fast initial consumption, the concentrations of lycopene, $\beta$-carotene, (not shown) and astaxanthin decayed almost linearly (Figs. 2C and 3C). A saturation in the autoxidation rate was observed when the $\mathrm{MbFe}^{\mathrm{III}}$ concentration was higher than 0.05 equiv. for lycopene and $\beta$-carotene and higher than 0.01 equiv. for astaxanthin. Interestingly, both bacterial carotenoid cocktails were almost insensitive to heme iron (Fig. 4C for GB1, not shown for HU36).

In the presence of $\mathrm{Fe}^{\mathrm{II}}$, there was a huge difference in stability between the standard carotenoids and the two groups of bacterial carotenoids (Fig. 5). The difference was not as pronounced with free $\mathrm{Fe}^{\mathrm{III}}$ and heme iron, but bacterial carotenoids still emerged as the most stable pigments.

\section{Tentative identification of carotenoid derivatives formed in the presence of iron}

After $4 \mathrm{~h}$ of reaction, similar chromatograms were obtained for a given carotenoid regardless of the initiator. With $\beta$-carotene, kinetic monitoring by UPLC-DAD-MS was performed (Fig. 6). (Z)Isomers and oxygenation products were detected after $1 \mathrm{~h}$ of reaction (Fig. 6A) among which (Z)- and (E)- $\beta$-carotene-5,8-epoxide, 5,6-epoxide, 5,6,5',6'-diepoxide and 5,8,5',8'-diepoxide were tentatively identified by their UV-vis absorption spectra and mass spectra, and by comparison with literature data [7] and mixtures of $\beta$-carotene epoxides compounds previously prepared as reference materials [54,55]. $\beta$-Carotene epoxides were no longer present after $4 \mathrm{~h}$ of reaction (Fig. 6B). Oxygenolysis products tentatively identified as (E)- $\beta$-apo-10'-carotenal, (E)- $\beta$-apo-12'-carotenal, 
Version définitive du manuscrit publiée dans / Final version of the manuscript published in :

Archives of Biochemistry and Biophysics (2015), Vol. 572, p. 89-100, DOI: 10.1016/j.abb.2014.12.030

Journal homepage : http://www.elsevier.com/locate/yabbi
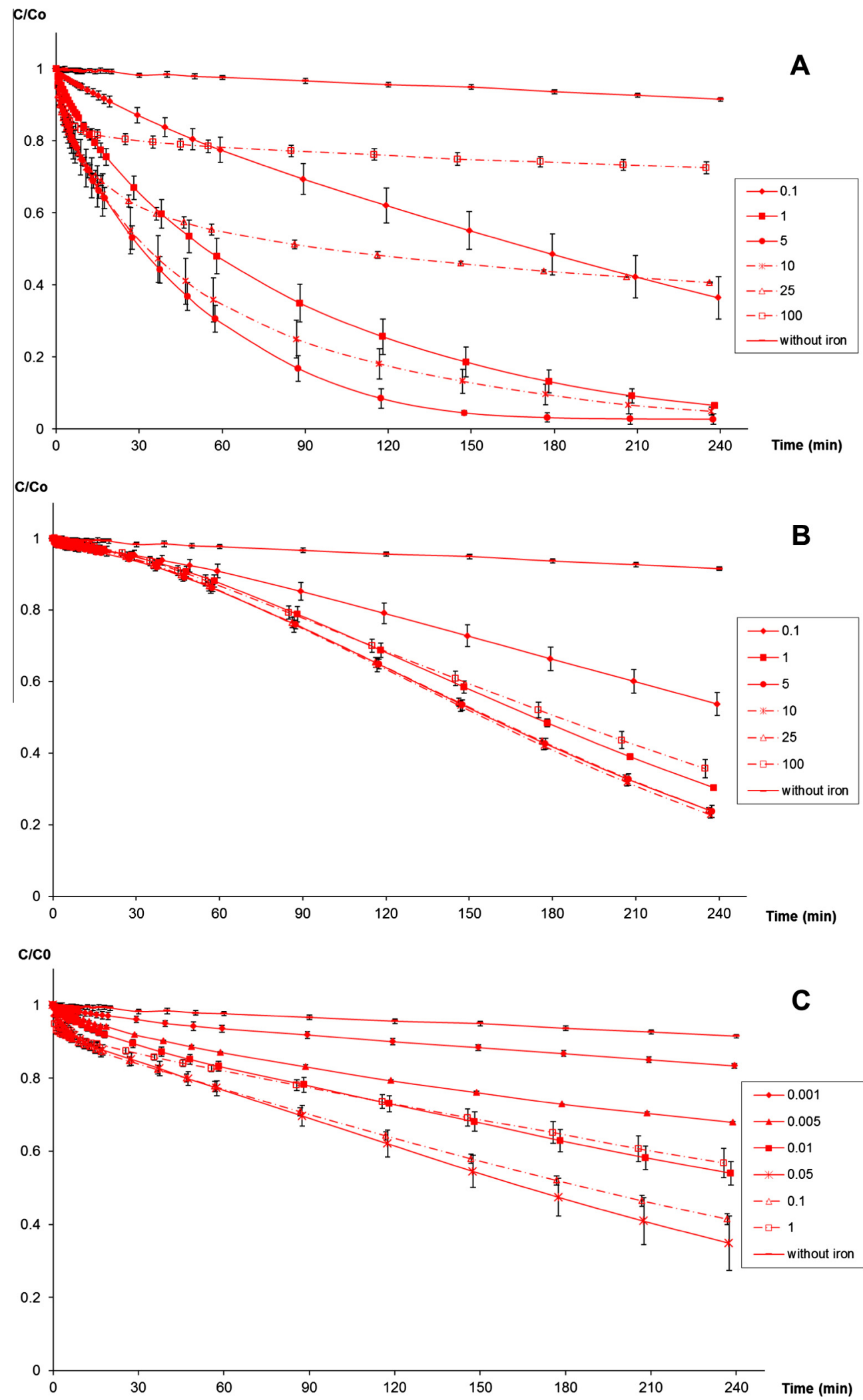

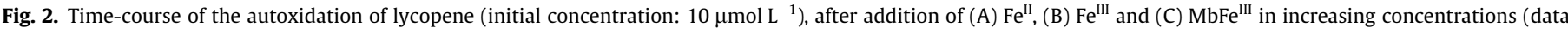
expressed as the molar fraction of residual carotenoid).

(E)- $\beta$-apo-14'-carotenal, (E)- $\beta$-apo-15-carotenal and $(E)$ - $\beta$-apo-13carotenone were observed after $1 \mathrm{~h}$, and some of these products were still detected after $4 \mathrm{~h}$ of reaction. Other products eluting earlier in the chromatogram (likely shorter-chain oxygenolysis prod- ucts) were also detected but could not be identified. In the presence of iron, lycopene was isomerized by approximately $30 \%$, and some oxygenation products were detected but could not be identified (results not shown). Products with a lower $\lambda_{\max }$ were 
Version définitive du manuscrit publiée dans / Final version of the manuscript published in :

Archives of Biochemistry and Biophysics (2015), Vol. 572, p. 89-100, DOI: 10.1016/j.abb.2014.12.030

Journal homepage : http://www.elsevier.com/locate/yabbi
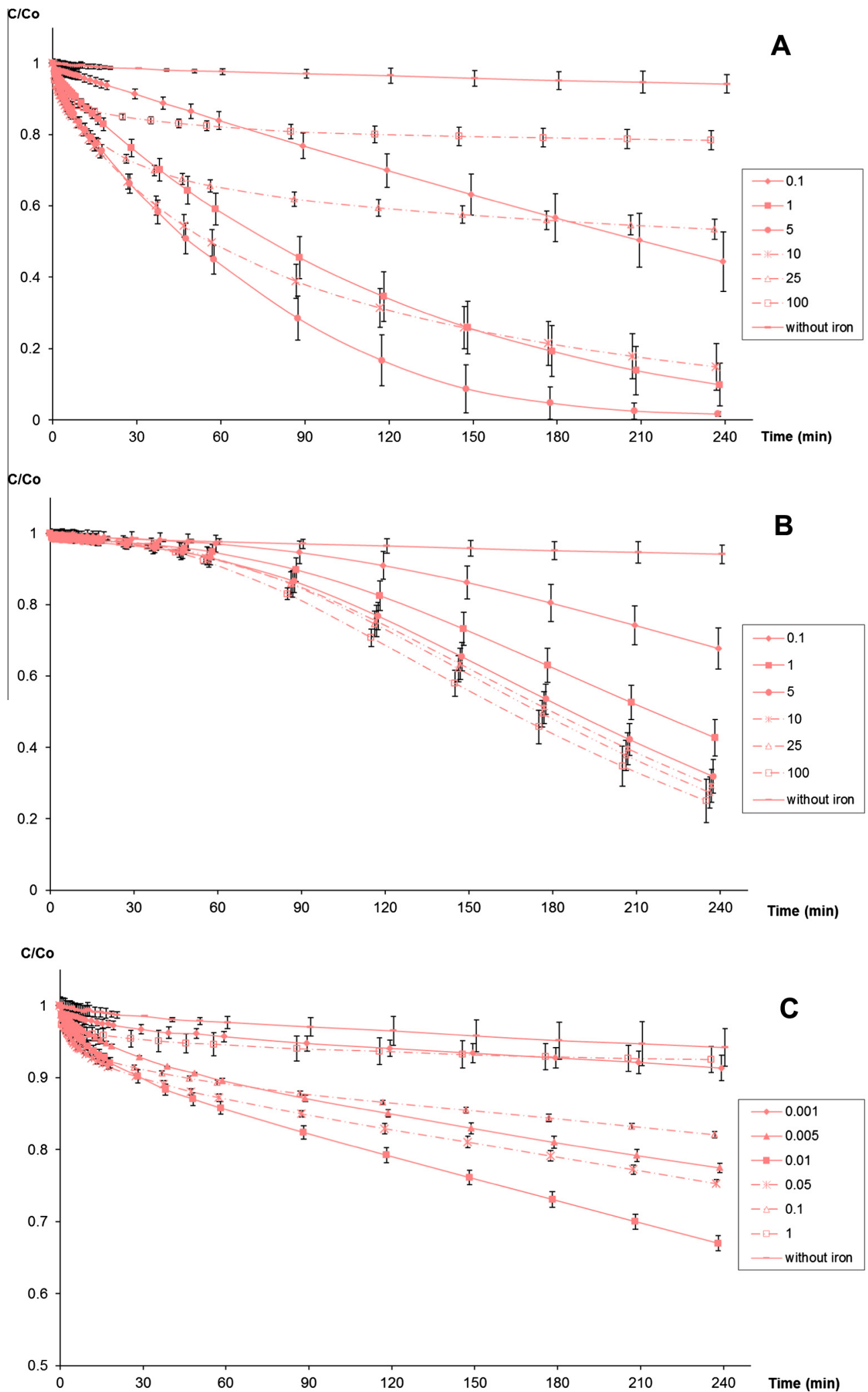

Fig. 3. Time-course of the autoxidation of astaxanthin (initial concentration: $10 \mu \mathrm{mol} \mathrm{L}^{-1}$ ), after addition of (A) Fe $\mathrm{F}^{\mathrm{II}}$, (B) $\mathrm{Fe}^{\mathrm{III}}$ and (C) $\mathrm{MbFe}^{\mathrm{III}}$ in increasing concentrations (data expressed as the molar fraction of residual carotenoid).

also detected after $4 \mathrm{~h}$ of iron-induced autoxidation of astaxanthin (absorption at 344, 412 and $430 \mathrm{~nm}$, results not shown), which suggests oxidative cleavage of the carbon chain of astaxanthin, but these products could not be identified.
The qualitative evaluation of the residual HU36 carotenoid content was achieved by reference to the apo-8'-phytoene peak used as an internal standard $\left(\mathrm{C}_{30} \mathrm{H}_{48}\right.$, precursor of carotenoids, stable during the experiment). The yellow carotenoid esters were 
Version définitive du manuscrit publiée dans / Final version of the manuscript published in :

Archives of Biochemistry and Biophysics (2015), Vol. 572, p. 89-100, DOI: 10.1016/j.abb.2014.12.030

Journal homepage : http://www.elsevier.com/locate/yabbi
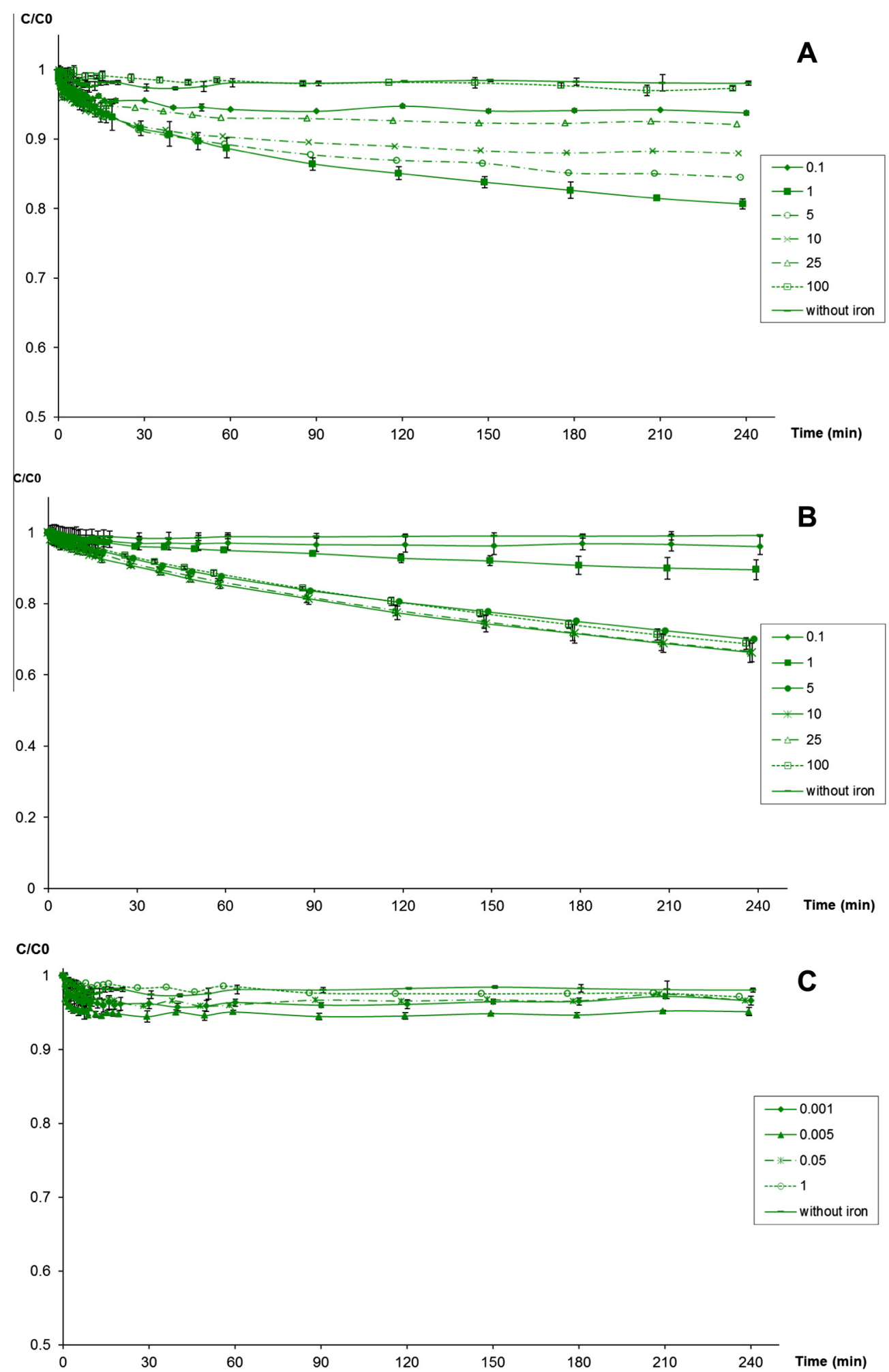

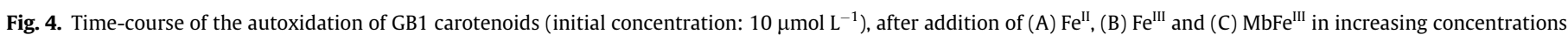
(data expressed as the molar fraction of residual carotenoid).

consumed first, while the orange carotenoid esters appeared to be more resistant (Fig. 7). Moreover, no additional peaks accounting for oxidation products were observed. Additional experiments with other solvents and a normal-phase column did not improve the analysis.

\section{Identification of volatile compounds}

During the reaction of the carotenoids with 5 equiv. $\mathrm{Fe}^{\mathrm{II}}$, volatile products were identified for some carotenoids using GC-MS. Analyses were performed every $40 \mathrm{~min}$ starting at 0 until $280 \mathrm{~min}$. The 


\section{Residual carotenoids $\left(\% \mathrm{C}_{\mathrm{t} 0}\right)$ $4 \mathrm{~h}$ after addition of iron}

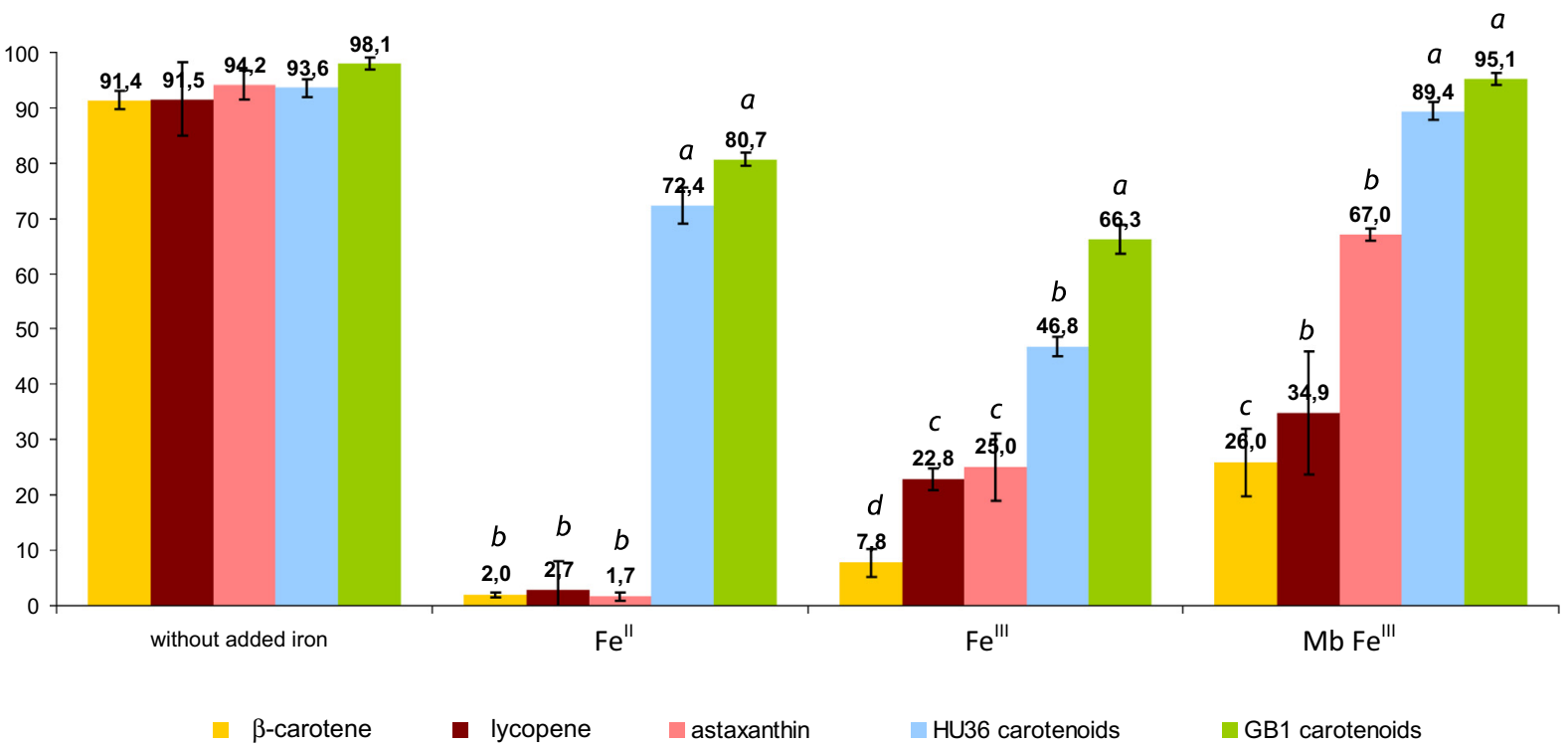

Fig. 5. Comparison of the stability of $\beta$-carotene, lycopene, astaxanthin, and purified bacterial carotenoids from HU36 and GB1 after $4 \mathrm{~h}$ of autoxidation at pH 4 , without iron and after the addition of three different forms of iron. Initial concentration of carotenoids: $10 \mu \mathrm{mol} \mathrm{L}^{-1}$, initial concentrations of iron selected so as to maximize autoxidation: $10-50 \mu \mathrm{mol} \mathrm{L}^{-1} \mathrm{Fe}^{\mathrm{II}}, 250-1000 \mu \mathrm{mol} \mathrm{L}{ }^{-1} \mathrm{Fe}^{\mathrm{III}}$ and $0.1-1.0 \mu \mathrm{mol} \mathrm{L}^{-1} \mathrm{MbFe}^{\mathrm{III}}$.

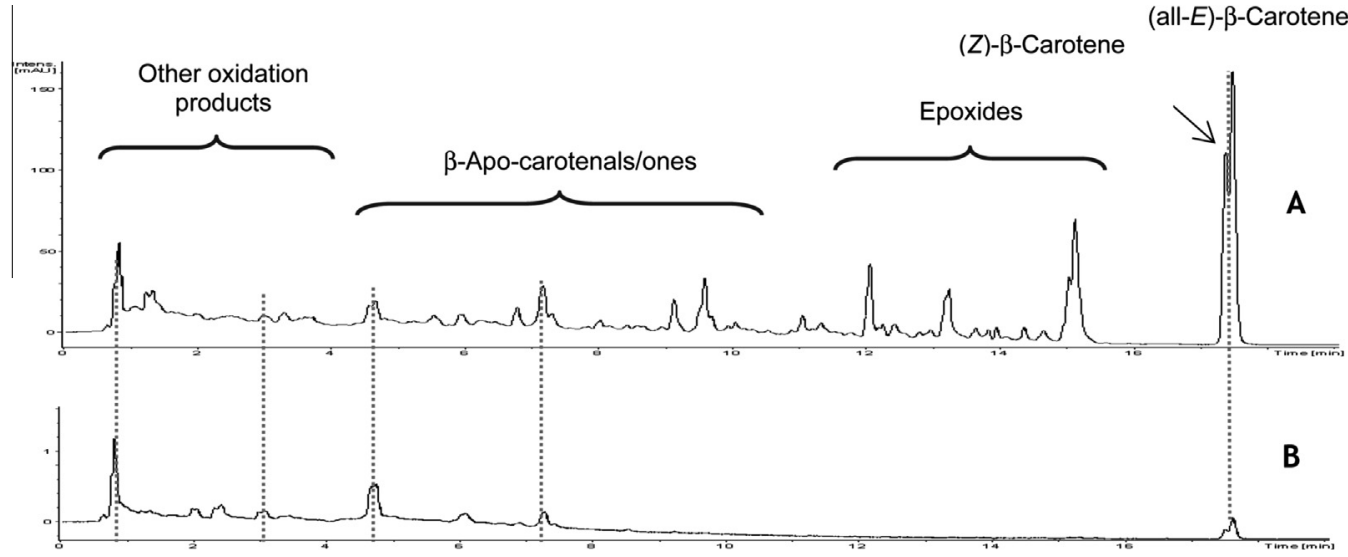

Fig. 6. UV-vis chromatograms (200-800 nm) of iron-induced autoxidation of $\beta$-carotene, (A) after $1 \mathrm{~h}$ of autoxidation, and (B) after $4 \mathrm{~h}$ of autoxidation.

fit of every single product compared to the reference data was higher than $75 \%$. With astaxanthin and bacterial carotenoids, no volatile products were detected. With $\beta$-carotene, several products were detected, peaks were integrated, and product accumulation was expressed as percentage of the final concentration measured (Fig. 8). $\beta$-Cyclocitral and $\beta$-ionone could be identified and quantified with commercial standards. These two products were initially detected after $40 \mathrm{~min}$, with a large increase observed between 40 and $80 \mathrm{~min}$, and then consistent increases observed until $280 \mathrm{~min}$. After $280 \mathrm{~min}$ of reaction $(50 \mathrm{nmol} \beta$-carotene $+250 \mathrm{nmol}$ $\left.\mathrm{Fe}^{\mathrm{II}}\right)$, approximately $2.5 \mathrm{nmol} \beta$-cyclocitral and $5 \mathrm{nmol} \beta$-ionone were measured. Other products were detected after $80 \mathrm{~min}$ : (2E,4E)-6,6-dimethyl-2,4-heptadiene, 2,2,6-trimethyl-cyclohexanone, 3,5,5-trimethyl-2-cyclohexen-1-one, 2,6,6-trimethyl-1cyclohexene-1-acetaldehyde, $\beta$-ionone-5,6-epoxide and 5,6,7, 7a-tetrahydro-4,4,7a-trimethyl-2(4H)-benzofuranone (=dihydroactinidiolide). Lycopene $(50 \mathrm{nmol})+$ iron $\left(250 \mathrm{nmol} \mathrm{Fe}^{\mathrm{II}}\right)$ released one major volatile product, 6-methyl-5-hepten-2-one, which level increased with time up to $0.5 \mathrm{nmol}$ after $280 \mathrm{~min}$.

\section{Discussion}

Like the reference carotenoids, the bacterial pigments were found to be rather stable at $\mathrm{pH} 4$ in the absence of iron over $4 \mathrm{~h}$. All carotenoids were more stable in the presence of heme iron than with both types of free iron over $4 \mathrm{~h}$, with bacterial carotenoids being the most stable. In fact, under mildly acidic conditions, $\mathrm{MbFe}^{\mathrm{III}}$ requires hydroperoxides to exert a strong pro-oxidant activity $[1,15]$. However, our results show that heme iron accelerates the autoxidation of reference carotenoids at much lower concentrations than free iron in our model.

The kinetics of $\mathrm{Fe}^{\mathrm{II}}$-induced autoxidation of both bacterial and reference carotenoids were two-step (bi-exponential model), but HU36 and GB1 carotenoids were more robust to oxidation than reference carotenoids. Previous studies reported a relationship between the structure and reactivity of carotenoids during oxidation $[36,39,59,43,47]$. With equally conjugated chain lengths, ketocarotenoids were found to be generally more stable than carotenes. Consistently, in this study, the initial rate of autoxidation 


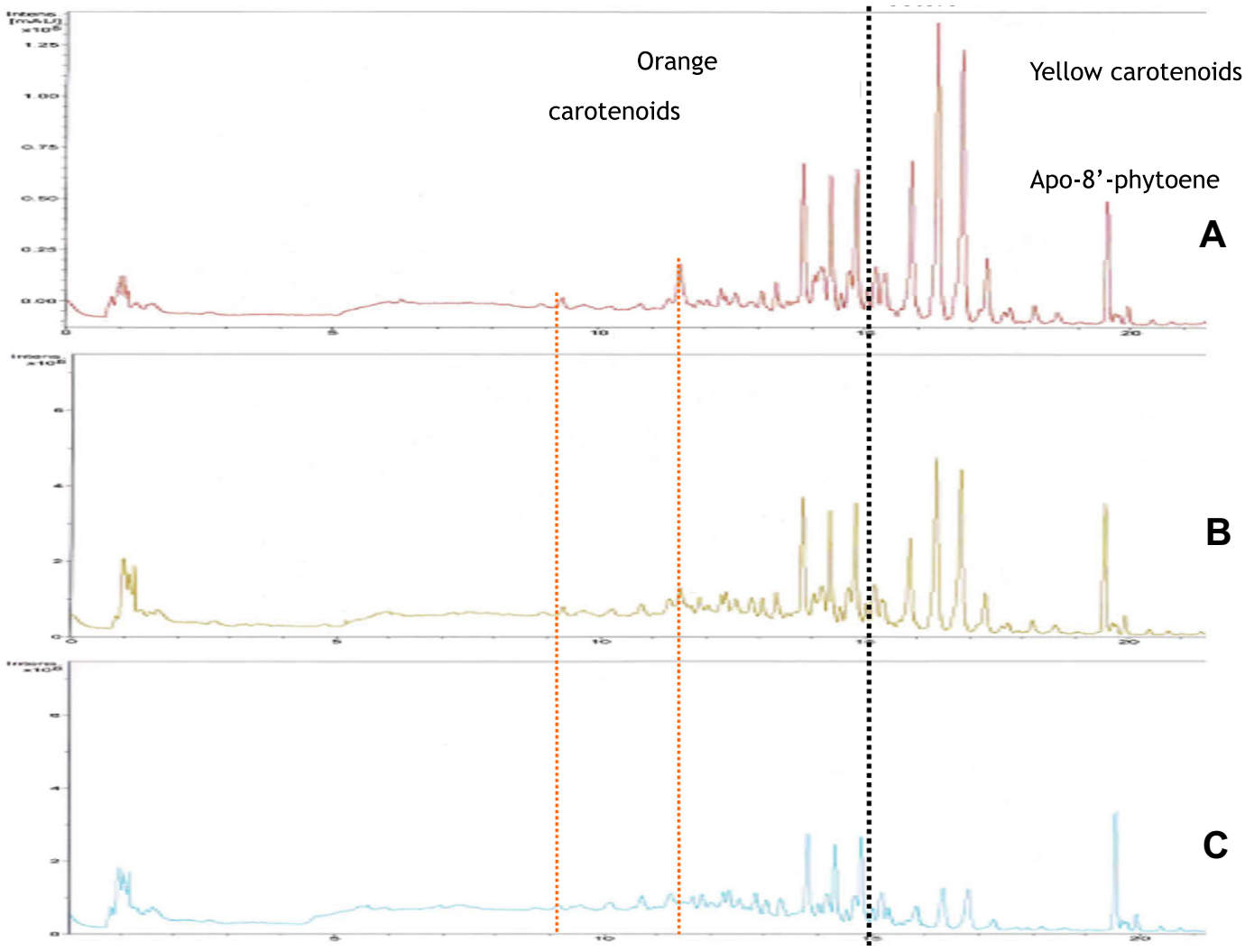

Fig. 7. UV-vis chromatograms of iron-induced autoxidation of HU36 carotenoids, (A) before the addition of iron, (B) after $1 \mathrm{~h}$ of autoxidation with 0.1 equiv. $\mathrm{Fe}^{\mathrm{II}}$ and (C) after $4 \mathrm{~h}$ of autoxidation with 25 equiv. $\mathrm{Fe}^{\mathrm{IIII}}$.

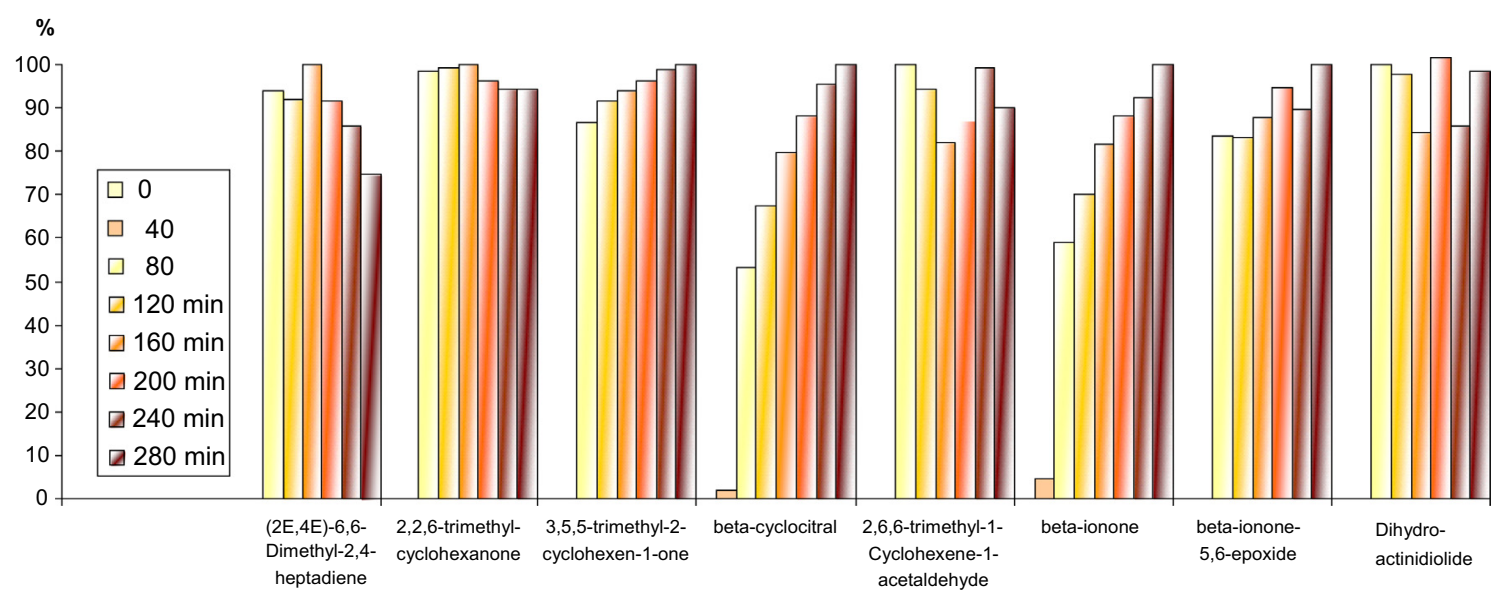

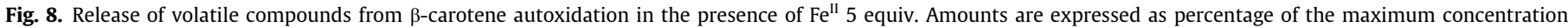
measured during the $4 \mathrm{~h}$ of reaction.

was found to be lower for astaxanthin than for the two carotenes. However, the reduction potentials of the corresponding radical cation are very close in micelles [8]. The higher polarity of astaxanthin, which probably favours its location close to the interface of the micelles, might be the dominant factor inducing a higher reactivity. Regarding the bacterial carotenoids, in addition to the effect of the carbonyl groups, the presence of the glycosyl and/or methyl groups at the ends of the polyene chain (Fig. 1) could also limit radical attacks. For all carotenoids, in large excess of $\mathrm{Fe}^{\mathrm{II}}$, less carotenoid was consumed. This result is consistent with our previous study on $\beta$-carotene $[54,55]$ and could be explained by the ability of $\mathrm{Fe}^{\mathrm{II}}$ to quench reactive iron-oxygen species involved in $\beta$-carotene consumption. This hypothesis was previously proposed to interpret the reactivity of lycopene with $\mathrm{Fe}^{\mathrm{II}}$ in oil-in-water emulsions [3].

In the presence of $\mathrm{Fe}^{\mathrm{III}}$, the oxidation of lycopene and astaxanthin displays a clear induction phase, which is much shorter with $\beta$-carotene and absent for the HU36 carotenoids. The induction phase is thought to correspond to the one-electron reduction of $\mathrm{Fe}^{\mathrm{III}}$ by carotenoids, thus releasing $\mathrm{Fe}^{\mathrm{II}}$. The rate of this electron transfer is proposed to vary in the following series: $\beta$-carotene $>$ lycopene $>$ astaxanthin. Consistently, lycopene is oxidized slightly more easily to its radical cation than astaxanthin $[8,40]$. Although xanthophylls having conjugated polyene chains with 
electro-withdrawing groups might be slightly less reducing than carotenes, this interpretation does not hold for the bacterial carotenoids. The polarity of carotenoids is another important factor to consider [19]. Indeed, xanthophylls in general and so glycosylated carotenoids in particular tend to be more localized at the edge of the micelles, thus being more exposed to oxidants in the aqueous phase.

Although their initial oxidation by $\mathrm{Fe}^{\mathrm{III}}$ was quite pronounced, the HU36 carotenoids were ultimately more stable against $\mathrm{Fe}^{\mathrm{III}}$ than the reference carotenoids. The reference carotenoids were also more rapidly oxidized than the bacterial carotenoids in the presence of hematin $\left(\mathrm{HmFe}^{\mathrm{III}}\right)$, the metmyoglobin cofactor, which is dissociated from the protein moiety (globin) at $\mathrm{pH} 4$ [20].

UPLC-DAD-MS analysis of iron-induced autoxidation of $\beta$-carotene revealed new products after $1 \mathrm{~h}$ of reaction resulting from isomerization, or oxidation, or oxidative cleavage of the $\beta$-carotene chain. After $4 \mathrm{~h}$, only shorter chain oxidative cleavage compounds were still present. Furthermore, volatile products could be detected during the whole duration of the experiment. We hypothesize that short chain oxygenolysis products and volatile compounds could either come from $\beta$-carotene directly, or from further oxidation of $\beta$-carotene epoxides and/or longer chain oxygenolysis products. (all-E)-Lycopene and its $(Z)$-isomer were still present after $4 \mathrm{~h}$ of reaction (results not shown), but oxidation products were barely detectable by LC-MS. In contrast, one volatile product, 6-methyl-5-hepten-2-one, was detected in significant amount with consistent increase between 40 and $280 \mathrm{~min}$. We hypothesize that the oxidation of lycopene into volatile compounds could be even quicker and/or more efficient than for $\beta$ carotene.

\section{Mechanistic insights}

A more detailed kinetic analysis of the iron-induced autoxidation of astaxanthin (AST) and the HU36 carotenoids provide some interesting insights in the complex underlying mechanisms.

Based on our previous work with $\beta$-carotene, the free ironinduced autoxidation of carotenoids displays the following characteristics:

- It is much faster when initiated with $\mathrm{Fe}^{\mathrm{II}}$ although a marked inhibition is observed when $\mathrm{Fe}^{\mathrm{II}}$ is in large excess. With $\mathrm{Fe}^{\mathrm{III}}$, the whole process is slowed down by the preliminary rate-limiting step of $\mathrm{Fe}^{\mathrm{III}}$ reduction by the carotenoid.

- A mixture of epoxides and cleavage products (aldehydes and ketones) is formed in agreement with O-atom transfer reactions from $\mathrm{Fe}^{\mathrm{II}}$ to $\mathrm{O}_{2}$ to the carotenoid.

- In an equimolar mixture of $\mathrm{Fe}^{\mathrm{II}}$ and carotenoid, the half-life of $\mathrm{Fe}^{\mathrm{II}}$ (reflecting its sensitivity to autoxidation into $\mathrm{Fe}^{\mathrm{III}}$ ) is much longer than in absence of carotenoid. This suggests that the oxygenation reactions (in competition with $\mathrm{Fe}^{\mathrm{II}}$ autoxidation) maintain iron in the low valence state.

The mechanism displayed on Scheme 1 correctly accounts for the experimental observations:

A kinetic analysis with astaxanthin and HU36 carotenoids shows close behaviours with $\mathrm{Fe}^{\mathrm{II}}$, i.e., a relatively fast consumption of carotenoids reaching saturation when $\mathrm{Fe}^{\mathrm{II}}$ is in excess (Fig. 3A, not shown for HU36 but similar to GB1 Fig. 4A, Fig. 9A and B). However, it is clear that $\mathrm{Fe}^{\mathrm{II}}$-induced autoxidation is much more efficient with AST as it is complete at low $\mathrm{Fe}^{\mathrm{II}}$ concentration $(\leqslant 5$ equiv.) and reaches saturation at high $\mathrm{Fe}^{\mathrm{II}}$ concentration $(>10$ equiv.), only. With HU36 carotenoids, $\mathrm{Fe}^{\mathrm{II}}$-induced autoxidation, which is maximal with 1 equiv. Fe ${ }^{\text {II }}$, remains partial in the whole range of $\mathrm{Fe}^{\mathrm{II}}$ concentration investigated. With an excess $\mathrm{Fe}^{\mathrm{II}}$, the decay of the carotenoid's visible band is bi-exponential with a fast

$$
\begin{aligned}
& \mathrm{Fe}^{\mathrm{II}}+\mathrm{O}_{2} \stackrel{\text { Fast }}{\rightleftharpoons} \mathrm{Fe}^{\mathrm{II}} \mathrm{O}_{2} \\
& \mathrm{Fe}^{\mathrm{II}} \mathrm{O}_{2}+\mathrm{Car} \stackrel{k_{\mathrm{ml}}}{\longrightarrow} \mathrm{CarO}+\mathrm{Fe}^{\mathrm{IV}} \mathrm{O} \\
& \mathrm{Fe}^{\mathrm{IV}} \mathrm{O}+\mathrm{Car} \stackrel{k_{\mathrm{m} 2}}{\longrightarrow} \mathrm{CarO}+\mathrm{Fe}^{\mathrm{II}} \quad \begin{array}{l}
\text { Mono- \& dioxygenation } \\
\text { reactions }
\end{array} \\
& \left.\mathrm{Fe}^{\mathrm{II}} \mathrm{O}_{2}+\mathrm{Car} \stackrel{k_{\mathrm{d}}}{\longrightarrow} \mathrm{CarO}_{2}+\mathrm{Fe}^{\mathrm{II}}\right\}^{\text {reactions }} \\
& \mathrm{Fe}^{\mathrm{II}} \mathrm{O}_{2}+\mathrm{Fe}^{\mathrm{II}} \stackrel{k_{\mathrm{q} 1}}{\longrightarrow} \mathrm{Fe}_{2}{ }_{2} \mathrm{O}_{2} \stackrel{2 \mathrm{H}^{\oplus}}{\longrightarrow} 2 \mathrm{Fe}^{\mathrm{III}}+\mathrm{H}_{2} \mathrm{O}_{2} \text { Q Quenching of } \\
& \left.\mathrm{Fe}^{\mathrm{IV}} \mathrm{O}+\mathrm{Fe}^{\mathrm{II}} \stackrel{k_{\mathrm{q} 2}}{\longrightarrow} \mathrm{Fe}_{2}^{\mathrm{III}}{ }_{2} \mathrm{O} \stackrel{2 \mathrm{H}^{\oplus}}{\longrightarrow} 2 \mathrm{Fe}^{\mathrm{III}}+\mathrm{H}_{2} \mathrm{O}\right\} \begin{array}{l}
\text { reactive iron } \\
\text { species by } \mathrm{Fe}^{\mathrm{II}}
\end{array} \\
& \mathrm{Fe}^{\mathrm{III}}+\mathrm{Car} \stackrel{k_{\mathrm{r}}}{\longrightarrow} \mathrm{Car}^{\bullet}+\mathrm{Fe}^{\mathrm{II}}
\end{aligned}
$$

Scheme 1. Proposed mechanism for the free iron-induced oxygenation of carotenoids.

component $k_{1}^{\text {obs }}$ of $c a .5-15 \times 10^{-3} \mathrm{~s}^{-1}$ that only involves a very limited carotenoid consumption $(<10 \%)$. At low $\mathrm{Fe}^{\mathrm{II}}$ concentration, the decay of the carotenoid's visible band becomes mono-exponential. Its apparent first-order rate constant is close to the slow component of the bi-exponential kinetics observed at higher $\mathrm{Fe}^{\mathrm{II}}$ concentration: $\quad k_{2}^{\text {obs }}=5-40 \times 10^{-5} \mathrm{~s}^{-1}$ for AST, $k_{2}^{\text {obs }}=6-$ $7 \times 10^{-5} \mathrm{~s}^{-1}$ for HU36.

Thus, both stoichiometric and kinetic parameters point to HU36 carotenoids being less sensitive to $\mathrm{Fe}^{\mathrm{II}}$-induced autoxidation than AST.

To get some mechanistic insight, a more detailed kinetic analysis can be proposed using a simplified version of Scheme 1 restricted to dioxygenation $\left(k_{\mathrm{m} 1}=k_{\mathrm{m} 2}=0, k_{\mathrm{q} 2}=0\right)$.

By merging $\mathrm{Fe}^{\mathrm{II}}$ and $\mathrm{Fe}^{\mathrm{II}} \mathrm{O}_{2}$ (in fast equilibrium), one can write:

$-\frac{d}{d t}\left(\mathrm{Fe}^{\mathrm{II}}\right)=\frac{d}{d t}\left(\mathrm{Fe}^{\mathrm{III}}\right)=2 k_{\mathrm{q} 1}\left(\mathrm{Fe}^{\mathrm{III}}\right)^{2}-k_{\mathrm{r}}\left(\mathrm{Fe}^{\mathrm{III}}\right)(\mathrm{Car})$

$-\frac{d}{d t}(\mathrm{Car})=k_{\mathrm{d}}\left(\mathrm{Fe}^{\mathrm{II}}\right)(\mathrm{Car})+k_{\mathrm{r}}\left(\mathrm{Fe}^{\mathrm{III}}\right)(\mathrm{Car})$

Using Eqs. (1) and (2), excellent curve-fittings ( $r>0.99$ ) of the curves of carotenoid consumption were obtained. Despite their substantial variability (Table 1 ), the values of rate constants $k_{\mathrm{d}}$ (dioxygenation) and $k_{\mathrm{q} 1}$ (quenching by excess $\mathrm{Fe}^{\mathrm{II}}$ ) suggest that HU36 carotenoids are not necessarily less prone to $\mathrm{Fe}^{\mathrm{II}}$-induced dioxygenation than AST but that the quenching of this mechanism by an excess $\mathrm{Fe}^{\mathrm{II}}$ may be more efficient with AST. If so, it means that this quenching cannot be written as simply as in Scheme 1, i.e., in a carotenoid-independent manner. It may be proposed that polar cleavage products formed in the dioxygenation step can interact with iron ions, thereby modulating the rate of $\mathrm{Fe}^{\mathrm{II}}$ autoxidation.

Regarding Fe ${ }^{\mathrm{III}}$-induced autoxidation, more contrasted behaviours were observed between AST and the HU36 carotenoids. With the latter, a mono-exponential decay of the visible band is observed (not shown but similar to GB1 Fig. 4B, $k^{\text {obs }}=7-20 \times 10^{-5} \mathrm{~s}^{-1}$ ) that is largely independent of the $\mathrm{Fe}^{\mathrm{III}}$ concentration and involves ca. 50\% carotenoid consumption (Fig. 9D). With AST, a pronounced induction period (carotenoid consumption $<10 \%$ ) is observed over $\mathrm{ca} .1 \mathrm{~h}$ (Fig. 2B), followed by a quasi-linear decay whose rate is essentially the same in the range 5-100 equiv. Fe ${ }^{\mathrm{III}}$. From a linear fitting of the carotenoid concentration over those 2 periods (10-100 equiv. $\mathrm{Fe}^{\mathrm{III}}$ ), the apparent first-order rate constants of $\mathrm{Fe}^{\mathrm{III}}$ reduction and carotenoid oxygenation can be estimated: $k_{\mathrm{r}}=1.1( \pm 0.2) \times 10^{-5} \mathrm{~s}^{-1}, k_{\mathrm{d}}=6.5$ $( \pm 0.1) \times 10^{-5} \mathrm{~s}^{-1}$. After $4 \mathrm{~h}$, up to $75 \%$ of AST is consumed. Thus, despite their initially faster reaction with $\mathrm{Fe}^{\mathrm{III}}$, HU36 carotenoids are globally less sensitive to $\mathrm{Fe}^{\mathrm{III}}$-induced autoxidation than AST. It may thus be proposed that HU36 carotenoids are better electron donors to $\mathrm{Fe}^{\mathrm{III}}$ than AST but that the Fe $\mathrm{F}^{\mathrm{II}}$-induced autoxidation thus triggered is more efficiently quenched by the HU36 
Version définitive du manuscrit publiée dans / Final version of the manuscript published in :

Archives of Biochemistry and Biophysics (2015), Vol. 572, p. 89-100, DOI: 10.1016/j.abb.2014.12.030

Journal homepage : http:/lwww.elsevier.com!locate!yabhi

$X$
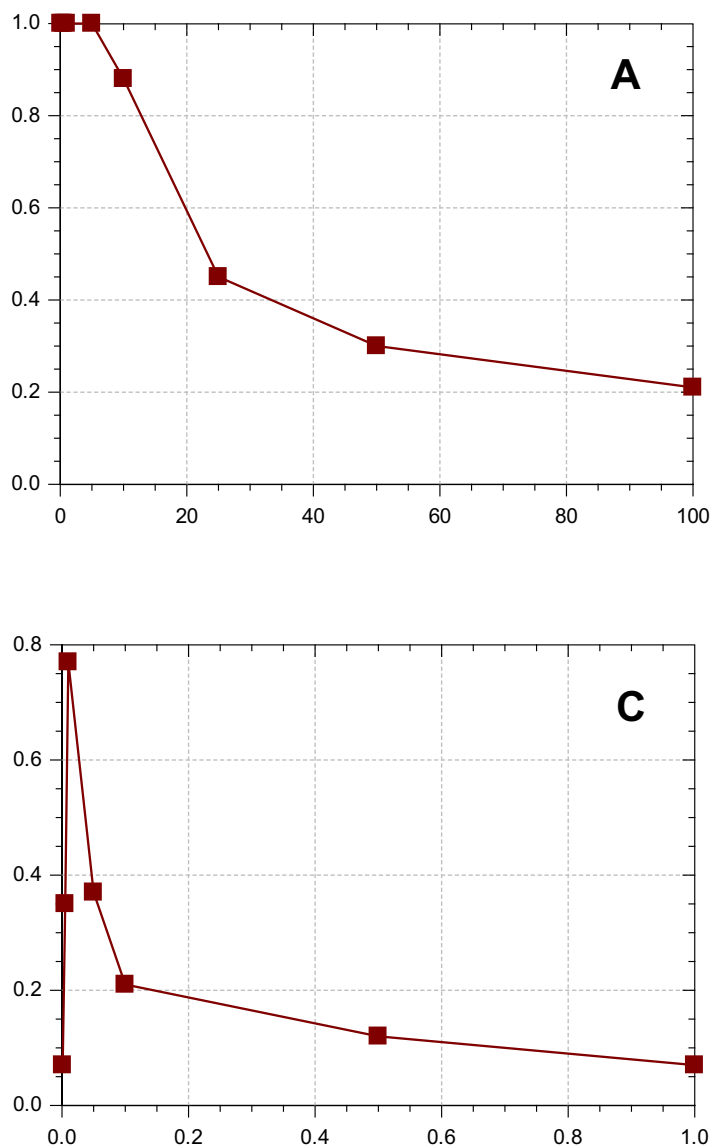
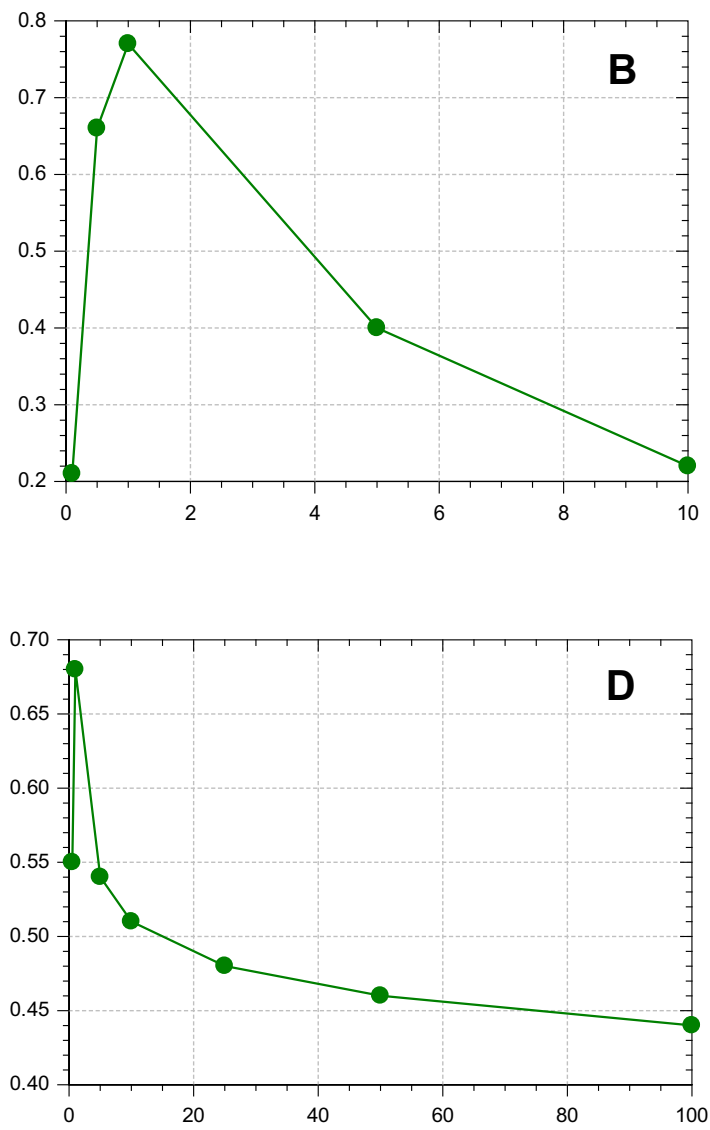

$\mathrm{Fe} /$ Carotenoid molar ratio

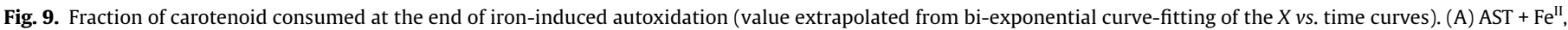
(B) $\mathrm{HU} 36+\mathrm{Fe}^{\mathrm{II}}$, (C) AST $+\mathrm{MbFe}^{\mathrm{III}}$, (D) $\mathrm{HU} 36+\mathrm{Fe}^{\mathrm{III}}$ (carotenoid concentration $=10 \mu \mathrm{M}$ ).

Table 1

Kinetic analysis of $\mathrm{Fe}^{\mathrm{II}}$-induced autoxidation of astaxanthin (AST) and HU36 carotenoids (initial carotenoid concentration $=10 \mu \mathrm{M}, \mathrm{pH} 4$ acetate buffer, $37^{\circ} \mathrm{C}$ ).

\begin{tabular}{llll}
\hline Car., $\mathrm{Fe}^{\mathrm{II}}$ (equiv.) & $k_{\mathrm{d}} / \mathrm{M}^{-1} \mathrm{~s}^{-1(\mathrm{a})}$ & $k_{\mathrm{q} 1} / \mathrm{M}^{-1} \mathrm{~s}^{-1(\mathrm{~b})}$ & $k_{\mathrm{r}} / \mathrm{M}^{-1} \mathrm{~s}^{-1(\mathrm{c})}$ \\
\hline AST, 0.1 & $53.0( \pm 0.7)$ & 0 & 0 \\
AST, 0.5 & $23.3( \pm 0.3)$ & 0 & 0 \\
AST, 1 & $15.7( \pm 0.3)$ & 0 & 0 \\
AST, 5 & $5.2( \pm 0.1)$ & 0 & 0 \\
AST, 10 & $7.4( \pm 0.6)$ & $33( \pm 7)$ & $1.05( \pm 0.04)$ \\
AST, 25 & $3.0( \pm 0.1)$ & $10.7( \pm 0.7)$ & 0 \\
AST, 50 & $1.83( \pm 0.02)$ & $12.6( \pm 0.2)$ & 0 \\
AST, 100 & $2.3( \pm 0.1)$ & $32.8( \pm 1.2)$ & 0 \\
HU36, 0.1 & $17.6( \pm 1.2)$ & $185( \pm 76)$ & $4.6( \pm 0.9)$ \\
HU36, 0.5 & $41.1( \pm 3.4)$ & $2540( \pm 380)$ & $6.34( \pm 0.04)$ \\
HU36, 1 & $22.7( \pm 1.3)$ & $499( \pm 56)$ & $3.12( \pm 0.02)$ \\
HU36, 5 & $14.2( \pm 1.1)$ & $369( \pm 43)$ & $0.25( \pm 0.01)$ \\
HU36, 10 & $40( \pm 7)$ & $1860( \pm 400)$ & $40( \pm 1) \times 10^{-3}$ \\
\hline
\end{tabular}

(a) $\mathrm{Fe}^{\mathrm{II}} \mathrm{O}_{2}+\mathrm{Car} \rightarrow \mathrm{Fe}^{\mathrm{II}}+\mathrm{CarO}_{2}$.

(b) $\mathrm{Fe}^{\mathrm{II}} \mathrm{O}_{2}+\mathrm{Fe}^{\mathrm{II}} \rightarrow 2 \mathrm{Fe}^{\mathrm{III}}+\mathrm{H}_{2} \mathrm{O}_{2}$.

(c) $\mathrm{Fe}^{\mathrm{III}}+\mathrm{Car} \rightarrow \mathrm{Fe}^{\mathrm{II}}+\mathrm{Car}^{+}$.

oxidation products, thereby resulting in less HU36 carotenoids being consumed.

As with $\mathrm{Fe}^{\mathrm{III}}$, heme-induced autoxidation allows a clear discrimination between AST and the HU36 carotenoids. While the latter are essentially stable (not shown but similar to GB1 Fig. 4C), AST is consumed through a bi-exponential mode with a fast component (Fig. 2C, $k_{1}^{\text {obs }}=2-40 \times 10^{-3} \mathrm{~s}^{-1}$ ) associated with very limited consumption of the carotenoid $(<10 \%)$ and a slow component $\left(k_{2}^{\text {obs }}=3-20 \times 10^{-5} \mathrm{~s}^{-1}\right)$ whose amplitude reaches a very sharp maximum with only 0.01 equiv. heme iron (Fig. 9C). Thus, AST is vulnerable to weak concentrations of heme iron but self-inhibition of astaxanthin oxygenation by larger concentrations of heme iron is very efficient.

The mechanism depicted in Scheme 2 can be proposed to account for the observations. It infers that large concentrations of heme iron favour the reaction between reduced heme species with concomitant production of hydrogen peroxide. Then, in agreement with an abundant literature [1,15], reaction between hematin and $\mathrm{H}_{2} \mathrm{O}_{2}$ leads to hypervalent heme, which (in the absence of the globin matrix) is rapidly degraded with simultaneous release of free $\mathrm{Fe}^{\mathrm{III}}$.

The fast component of the bi-exponential AST consumption could reflect the limited reduction of hematin by AST. If so, this step is much faster than the corresponding reduction of free $\mathrm{Fe}^{\mathrm{III}}$. The slow component can be ascribed to the oxygenation pathway itself. The values of its apparent rate constant are of the same order of magnitude as with free iron. Surprisingly, the HU36 carotenoids do not reduce hematin. As these carotenoids may be better electron donors than AST (cf. investigation with free $\mathrm{Fe}^{\mathrm{III}}$ ), these distinct behaviours could rather suggest that preliminary 


$$
\begin{aligned}
& \mathrm{HmFe}^{\mathrm{III}}+\mathrm{Car} \stackrel{k_{\mathrm{r}}}{\longrightarrow} \mathrm{Car}^{\bullet}+\mathrm{HmFe}^{\mathrm{II}} \\
& \mathrm{HmFe}^{\mathrm{II}}+\mathrm{O}_{2} \stackrel{\text { Fast }}{\rightleftharpoons} \mathrm{HmFe}^{\mathrm{II}} \mathrm{O}_{2} \stackrel{\mathrm{Car}}{\longrightarrow} \text { Oxygenated Car products } \\
& \mathrm{HmFe}^{\mathrm{II}}+\mathrm{HmFe}^{\mathrm{II}} \mathrm{O}_{2} \stackrel{2 \mathrm{H}}{\longrightarrow} 2 \mathrm{HmFe}^{\mathrm{III}}+\mathrm{H}_{2} \mathrm{O}_{2}
\end{aligned}
$$

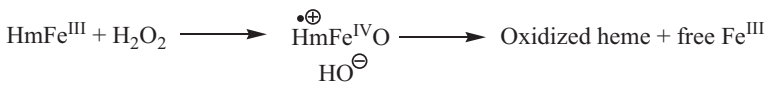

Scheme 2. Proposed mechanism for the heme iron-induced oxygenation of carotenoids.

heme-carotenoid binding (effective with AST, ineffective with HU36) is important to prime the whole mechanism.

\section{Conclusion}

Bacterial carotenoids were found to be significantly more stable against three forms of dietary iron in a mildly acidic micellar system than $\beta$-carotene, lycopene, and astaxanthin. The different reactivity of the carotenoids with iron can be explained by differences in electron-donating capacity, location within micelles, affinity for heme and interactions between iron ions and carotenoid oxygenation products. Moreover, we have recently shown that these bacterial carotenoids are better antioxidants against lipid peroxidation than reference carotenoids in a model of the gastric compartment [54,55]. Collectively, the unique properties of these bacterial carotenoids make them very interesting for future technological applications (e.g., as stable colourants) and nutritional applications.

\section{Acknowledgments}

This work was supported by a grant from the European Community's Seventh Framework Program (Colorspore, No. 207948, "New sources of natural, gastric stable, food additives, colorants and novel functional foods", which was a small collaborative project coordinated by Simon Cutting, Royal Holloway University of London, within the work program topic "(Bio)Technologies for the production of food additives, and flavours (KBBE-2007-2-3$03)$ ). This publication reflects only the authors' view. The Colorspore community is not liable for any use that may be made of the results. Special thanks are given to Paul Fraser, Laura PerezFons and Reena Khaneja (Royal Holloway University of London, UK) for providing carotenoid-rich bacterial extracts. We thank the company Conesa (Conservas Vegetales de Extremadura, Badajoz, Spain) for its gift of (all-E)-lycopene. We also thank Michel Carail (INRA) for his technical assistance with the UPLC-DAD-MS analysis, Christian Ginies (INRA) for his help with the GC-MS analysis and Rachel Kopec for the critical reading of the manuscript.

\section{References}

[1] C.P. Baron, H.J. Andersen, J. Agric. Food Chem. 50 (14) (2002) 3887-3897.

[2] F. Böhm, R. Edge, et al., Mol. Nutr. Food Res. 56 (2) (2012) 205-216.

[3] C.S. Boon, D.J. McClements, et al., J. Agric. Food Chem. 57 (2009) 2993-2998.

[4] C.S. Boon, D.J. McClements, et al., Crit. Rev. Food Sci. Nutr. 50 (6) (2010) 515532.

[5] P. Borel, Clin. Chem. Lab. Med. 41 (8) (2003) 979-994.

[6] G. Britton, S. Liaaen-Jensen, et al., Carotenoids, volume 1B: Spectroscopy, Birkhäuser Verlag AG, Basel, Switzerland, 1994.
[7] G. Britton, S. Liaaen-Jensen, et al., Carotenoids Handbook, Birkhäuser, Basel, 2004.

[8] M. Burke, R. Edge, et al., FEBS Lett. 500 (3) (2001) 132-136.

[9] G.W. Burton, J. Daroszewski, et al., Can. J. Chem. 92 (4) (2014) 305-316.

[10] B.P. Chew, J.S. Park, in: G. Britton, S. Liaaen-Jensen, H. Pfander (Eds.) Carotenoids, volume 5: Nutrition and Health, Birkhäuser Verlag AG, Basel, Switzerland, 2009, pp. 363-382.

[11] L.H. Duc, P.D. Fraser, et al., FEMS Microbiol. Lett. 255 (2) (2006) 215-224.

[12] L. Dufossé, in: G. Britton, S. Liaaen-Jensen, H. Pfander (Eds.), Carotenoids volume 5: Nutrition and Health, Birkhäuser Verlag AG, Basel, Switzerland, 2009, pp. 363-382.

[13] R. Edge, D.J. McGarvey, et al., J. Photochem. Photobiol. B - Biol. 41 (3) (1997) $189-200$.

[14] A. El-Agamey, G.M. Lowe, et al., Arch. Biochem. Biophys. 430 (1) (2004) 37-48.

[15] C. Faustman, Q. Sun, et al., Meat Sci. 86 (1) (2010) 86-94.

[16] E.I. Finkelshtein, I.S. Krasnokutskaya, J. Phys. Org. Chem. 9 (6) (1996) 411-418.

[17] G.Q. Gao, Y. Deng, et al., J. Phys. Chem. B 101 (39) (1997) 7844-7849.

[18] Y.L. Gao, L.D. Kispert, J. Phys. Chem. B 107 (22) (2003) 5333-5338.

[19] P. Goupy, E. Reynaud, et al., New J. Chem. 36 (2012) 575-587.

[20] P. Goupy, E. Vulcain, et al., Free Radical Biol. Med. 43 (6) (2007) 933-946.

[21] G.J. Handelman, F. Vankuijk, et al., Free Radical Biol. Med. 10 (6) (1991) $427-$ 437.

[22] L.K. Henry, N.L. Puspitasari-Nienaber, et al., J. Agric. Food Chem. 48 (10) (2000) 5008-5013.

[23] H.A. Hong, J.M. Huang, et al., J. Appl. Microbiol. 105 (2) (2008) 510-520.

[24] H.A. Hong, R. Khaneja, et al., Res. Microbiol. 160 (2) (2009) 134-143.

[25] E.J. Johnson, N.I. Krinsky, in: G. Britton, S. Liaaen-Jensen, H. Pfander (Eds.) Carotenoids, volume 5: Nutrition and Health, Birkhäuser Verlag AG, Basel, Switzerland, 2009, pp. 287-300.

[26] E.J. Johnson, R. Vishwanathan, et al., J. Ageing Res. (2013)

[27] J. Kanner, T. Lapidot, Free Radical Biol. Med. 31 (11) (2001) 1388-1395.

[28] R. Khaneja, L. Perez-Fons, et al., J. Appl. Microbiol. 108 (6) (2010) 1889-1902.

[29] S.J. Kim, Food Sci. Biotechnol. 13 (2) (2004) 202-207.

[30] T. Lapidot, R. Granit, et al., J. Agric. Food Chem. 53 (9) (2005) 3383-3390.

[31] G. Lombardi-Boccia, B. Martinez-Dominguez, et al., J. Food Sci. 67 (5) (2002) $1738-1741$

[32] J.R. Mancuso, D.J. McClements, et al., J. Agric. Food Chem. 47 (10) (1999) 4146 4149 .

[33] J.R. Marshall, G.J. Wilmoth, J. Bacteriol. 147 (3) (1981) 900-913.

[34] H.D. Martin, C. Ruck, et al., Pure Appl. Chem. 71 (12) (1999) 2253-2262.

[35] A. Mikkelsen, L.H. Skibsted, Z. Lebensm. Unters. - Forsch. 200 (1995) 171-177.

[36] N.J. Miller, J. Sampson, et al., FEBS Lett. 384 (1996) 240-242.

[37] R.C. Mordi, J.C. Walton, et al., Tetrahedron 49 (4) (1993) 911-928.

[38] A. Mortensen, in: G. Britton, S. Liaaen-Jensen, H. Pfander (Eds.), Carotenoids, volume 5: Nutrition and Health, Birkhäuser Verlag AG, Basel, Switzerland, 2009, pp. 67-82.

[39] A. Mortensen, L.H. Skibsted, J. Agric. Food Chem. 45 (8) (1997) 2970-2977.

[40] A. Mortensen, L.H. Skibsted, et al., Arch. Biochem. Biophys. 385 (1) (2001) 1319.

[41] P. Palozza, S. Serini, et al., in: G. Britton, S. Liaaen-Jensen, H. Pfander (Eds.) Carotenoids, volume 5: Nutrition and Health, Birkhäuser Verlag AG, Basel, Switzerland, 2009, pp. 211-234.

[42] L. Perez-Fons, S. Steiger, et al., Biochim. Biophys. Acta (BBA) - Mol. Cell Biol. Lipids 1811 (3) (2011) 177-185.

[43] A. Perez-Galvez, M.I. Minguez-Mosquera, J. Agric. Food Chem. 49 (10) (2001) 4864-4869.

[44] A.V. Rao, L.G. Rao, Pharmacol. Res. 55 (3) (2007) 207-216.

[45] C.E. Realini, A. Vénien, et al., Meat Sci. 94 (2013) 408-416.

[46] C.L. Rock, in: G. Britton, S. Liaaen-Jensen, H. Pfander (Eds.), Carotenoids volume 5: Nutrition and Health, Birkhäuser Verlag AG, Basel, Switzerland, 2009, pp. 269-286.

[47] E. Rodrigues, L.R.B. Mariutti, et al., Food Chem. 135 (3) (2012) 2103-2111.

[48] E.B. Rodriguez, D.B. Rodriguez-Amaya, Food Chem. 101 (2) (2007) 563-572.

[49] S. Sabour-Pickett, J.M. Nolan, et al., Mol. Nutr. Food Res. 56 (2) (2012) 270-286.

[50] W. Schalch, J.T. Landrum, et al., in: G. Britton, S. Liaaen-Jensen, H. Pfander (Eds.), Carotenoids, volume 5: Nutrition and Health, Birkhäuser Verlag AG, Basel, Switzerland, 2009, pp. 287-334.

[51] L.H. Skibsted, J. Agric. Food Chem. 60 (10) (2012) 2409-2417.

[52] W. Stahl, N. Ale-Agha, et al., Biol. Chem. 383 (3-4) (2002) 553-558.

[53] W. Stahl, H. Sies, Mol. Aspects Med. 24 (6) (2003) 345-351.

[54] C. Sy, C. Caris-Veyrat, et al., Food Funct. 4 (5) (2013) 698-712.

[55] C. Sy, O. Dangles, et al., Free Radic. Biol. Med. 63 (2013) 195-206.

[56] A. Takahashi, N. Shibasaki-Kitakawa, et al., J. Am. Oil Chem. Soc. 76 (8) (1999) 897-903.

[57] V. Tyssandier, E. Reboul, et al., Physiology 284 (6) (2003) G913-G923.

[58] C.C. Wei, G.Q. Gao, et al., J. Chem. Soc. - Perkin Trans. 2 (4) (1997) 783-786.

[59] A.A. Woodall, L.S. Wai-Ming, et al., Biochem. Biophy. Acta 1336 (1997) 33-42. 